\title{
Immunological mechanism of postherpetic neuralgia and effect of pregabalin treatment on the mechanism: a prospective single-arm observational study
}

\author{
Aysel Mercan ${ }^{1}$, Sema Tuncer Uzun ${ }^{2}$, Sevgi Keles ${ }^{3}$, Gulcin Hacibeyoglu $^{1}$, Resul Yilmaz $^{1}$, and Ruhiye Reisli ${ }^{2}$ \\ 'Department of Anesthesiology and Reanimation, Necmettin Erbakan University Meram Faculty of Medicine, Konya, Turkey \\ ${ }^{2}$ Division of Algology, Department of Anesthesiology and Reanimation, Necmettin Erbakan University Meram Faculty of Medicine, Konya, Turkey \\ ${ }^{3}$ Division of Pediatric Allergy and Immunology, Department of Pediatric Health, Necmettin Erbakan University Meram Faculty of Medicine, Konya, \\ Turkey
}

Received May 13, 2021

Revised July 9, 2021

Accepted July 9, 2021

Handling Editor: Jeong-Gill Leem

\section{Correspondence}

Aysel Mercan

Department of Anesthesiology and Reanimation, Necmettin Erbakan University Meram Faculty of Medicine, Yunus Emre District, Akyokus street, 42080 Meram/Konya, Turkey

Tel: +90-554-768-62-70

Fax: +90-332-223-61-81

E-mail: ayselyazarmercan@gmail.com
Background: Although neuropathic pain is a severe and common pain, its pathophysiology has not been elucidated yet. Studies in recent years have focused on the immune system's role in the pathogenesis of neuropathic pain. The aim of this study was to investigate the role of immunological mechanisms in neuropathic pain and the effect of pregabalin by measuring immunological marker levels in peripheral blood before and after pregabalin treatment in postherpetic neuralgia (PHN) patients with neuropathic pain.

Methods: Forty patients diagnosed with PHN were included in the study. CD4, T follicular cells (Tfh: CD4 $\left.{ }^{+} \mathrm{CXCR}^{+} \mathrm{PD} 1^{+}\right)$, Th17 $\left(\mathrm{CD} 4^{+} \mathrm{CCR} 6^{+}\right.$and $\left.\mathrm{CD} 4^{+} \mathrm{IL} 17 \mathrm{~A}^{+}\right)$, regulatory T cells (Treg: $\mathrm{CD} 4^{+} \mathrm{CD} 25^{+}$foxp $\left.3^{+}\right)$, Th1 $\left(\mathrm{CD} 4^{+} \mathrm{CXCR}^{+}\right.$and $\left.\mathrm{CD} 4^{+} \mathrm{IFN}-\gamma^{+}\right)$and Th2 $\left(\mathrm{CD} 4^{+}\right.$ $\left.\mathrm{IL}-4^{+}\right)$cell ratios were measured in peripheral blood samples before treatment and after 3 months of treatment.

Results: When immunological marker and inflammation parameter levels were compared before and after treatment, the helper $\mathrm{T}$ cell ratio $\left(\mathrm{CD}^{+}, \mathrm{CD}^{+}\right)$was $30.28 \pm 12.27 \%$ before treatment and $34.93 \pm 11.70 \%$ after treatment, so there was a statistically significant increase $(P=0.028)$. Th17 was $4.75 \pm 5.02 \%$ before treatment and $5.80 \pm 3.13 \%$ after treatment, and there was a statistically significant increase $(P=0.036)$.

Conclusions: Immunological mechanisms play an essential role in the pathogenesis of neuropathic pain, immunologically based treatment approach will be the critical point of treatment.

Key Words: Cytokines; Immune System; Interleukin-17; Neuralgia, Postherpetic; Pain; Pregabalin; Th17 Cells; T-Lymphocytes, Regulatory.

\section{INTRODUCTION}

Neuropathic pain is a severe and common type of pain affecting approximately $18 \%$ of the population [1]. Despite extensive research, to date, the pathophysiological mechanisms in the development of neuropathic pain have not been clearly revealed. Recent studies show that the immune system plays an essential role in developing neuropathic pain [2-4]. Many neuropathic pain causes, but the most common neuropathic pain causes in clinical practice (c) This is an open-access article distributed under the terms of the Creative Commons Attribution Non-Commercial License (http://creativecommons.org/licenses/by-nc/4.0/), which permits unrestricted non-commercial use, distribution, and reproduction in any medium, provided the original work is properly cited.

(c) The Korean Pain Society, 2021
Author contributions: Aysel Mercan: Writing/manuscript preparation; Sema Tuncer Uzun: Supervision; Sevgi Keles: Investigation; Gulcin Hacibeyoglu: Writing/manuscript preparation; Resul Yilmaz: Resources; Ruhiye Reisli: Project administrantion. 
are diabetic neuropathy and postherpetic neuralgia (PHN) $[5,6]$.

Varicella-Zoster virus (VZV) is a double-stranded and enveloped DNA virus that can remain latent in cranial nerves and dorsal root ganglia for years after chickenpox infection. In cases where the immune system is weakened, the virus that remains latent in the dorsal root ganglia becomes active. It causes a disease called zona zoster, characterized by painful, vesiculobullous lesions limited to unilateral dermatomes [7]. Although the lesions disappear in 2-4 weeks, some patients continue to have pain. Pain that persists for more than three months is called PHN [8]. PHN is a treatment-resistant chronic pain syndrome [9]. Risk factors for PHN include advanced age, severe symptoms, and chronic diseases with suppressed immune systems such as malignancy and diabetes $[9,10]$. Many studies have previously been conducted investigating the relationship between neuropathic pain, PHN, and the immune system [11-18].

Th1, Th2, Th17, and Treg (CD4, CXCR5, CCR6, FOXP3, CD25, IFN- $\gamma$, IL-17 ve IL-4) cell levels were studied before and after treatment to evaluate the role of immune mechanisms in the development and chronicity of neuropathic pain, as well as the effect of pregabalin treatment on these mechanisms in patients with PHN.

The literature was scanned during the present study's design phase. Proinflammatory cytokines have been associated with neuropathic pain, and anti-inflammatory cytokine potentiation was thought to alleviate neuropathic pain $[19,20]$. Some publications have focused on $\mathrm{T}$ cells, which are considered key players of the adaptive immune system $[21,22]$. Th1 has been shown to mediate neuropathic pain [23]. There have also been many animal studies investigating cytokines in neuropathic pain $[3,24]$. In a study, the administration of an antibody that reduced $\mathrm{CD}^{+} \mathrm{T}$ cells in mice suppressed thermal hyperalgesia and allodynia [25]. In another study, IL- $4^{+}$was applied to damaged nerves, and it was shown to reduce neuropathic pain [26]. The analgesic effect of IL- $4^{+}$has also been demonstrated in inflammatory and neuropathic pain models [27]. Mice lacking IFN- $\gamma$ have been shown to have less mechanical sensitivity [28]. Treg cells [21] have also recently been the focus of attention of researchers. It has been shown that Treg cells are involved in endogenous healing [29] and that there is an increase in Treg cells in PHN $[18,29]$. In a study conducted in mice, IL-17 was influential in neuropathic pain after peripheral nerve injury [15]. IL17 is thought to be effective in increasing hypersensitivity and chronic neuropathic pain process.

The authors want to emphasize the importance of IL17. Because the Food and Drug Administration approved IL-17 inhibitory monoclonal antibody (Secukinumab), it is currently used to treat autoimmune diseases. It may be an alternative for preventing chronic neuropathic pain in the future [30]. The authors aimed to combine the most frequently investigated cytokines in the pathogenesis of neuropathic pain in a single study. They hypothesized that the immune system plays a crucial role in the formation of neuropathic pain and that pregabalin treatment provides recovery by affecting immunological mechanisms. There have been many studies on neuropathic pain and its immunological mechanisms, but this study is the first to examine the effect of pregabalin on the immune system.

\section{MATERIALS AND METHODS}

\section{Ethics statement}

This study was carried out prospectively at Necmettin Erbakan University Meram Medical Faculty Hospital Algology Polyclinic between November 2018 and February 2020. The study followed the Declaration of Helsinki principles and was approved by the ethics committee of the NEU Meram Medical Faculty (decision dated 17.10.2018 with the ethical approval number 2018/173) and the ethics committee of the Republic of Turkey ministry of health (approval number 93189304-514.04.01-E.193687). The study was financed by the scientific research projects coordinator of NEU (project number: 181518025).

\section{Patients}

Patients with PHN between the ages of 18-80 were included in the study. Patients who had previously received treatment for neuropathic pain, pregabalin treatment for a different reason, with chronic renal failure (creatinine $>2 \mathrm{mg} / \mathrm{dL}$ ), liver dysfunction, malignancy, a history of cerebrovascular disease, autoimmune disease, psychiatric disease, and drug addiction, who were pregnant or breastfeeding woman, who had diagnosed immunodeficiency, and who did not agree to volunteer were excluded from the study. The patients' written consent forms were obtained, and a record was made of their gender and age, the presence of any comorbidities, any medical treatments applied, as well as their score on the $0-10$ point numeric rating scale (NRS). In addition to routine blood tests (hemogram, erythrocyte sedimentation rate [ESR], C-reactive protein [CRP]), immunological marker levels were also measured at the patients' first admission. All patients were started on $150 \mathrm{mg} /$ day oral pregabalin treatment following the European Federation of Neurological Societies neuropathic pain guideline $[20,31]$. The patients were checked regularly every month, and the dose was adjusted accord- 
ing to the patients" NRS scores, clinical status, and drug side effects. Immunological markers, sedimentation, and CRP levels were studied from the peripheral blood sample at the end of the third month of treatment.

\section{Flow cytometric staining and analysis}

Peripheral blood mononuclear cells were isolated from the $5 \mathrm{~mL}$ blood sample taken from the patients' ethylenediaminetetraacetic acid for routine laboratory studies. Surface staining was performed on these cells by adding antibodies CD4 (APC), PD1 (FITC-A), CCR6 (PE-Cy7), CXCR3 (APC), and CXCR5 (PerCP-Cy5.5) obtained from Becton Dickinson (BD, Franklin Lakes, NJ). After the cells were kept in the dark for 20 minutes, the cells were fixed using BD Perm/Wash Buffer and permeabilized. In the following period, the cells were stained with the FOXP3 (BV421) antibody obtained from BD using the intracellular staining technique, and the cells were analyzed on the BD FACS Canto II device. Some of the peripheral blood mononuclear cells obtained for cytokine release were incubated with sodium pyruvate non-essential amino acid $\mathrm{T}$ cell activation kit for four days at $37^{\circ} \mathrm{C}$ in a $\mathrm{CO}_{2}$ oven. The cells were then washed once with phosphate buffer solution (PBS), stimulated with phorbol myristate acetate/ionomycin for 4 hours, and then surface staining was done with CD4 antibody. The cells were then fixed with Perm/Wash Buffer. Staining was done by adding IL-4, IL-17A, and IFN- $\gamma$ antibodies to the cells. Following this staining, it was washed with PBS and analyzed on a BD FACS Canto II instrument. $\mathrm{CD}^{+}, \mathrm{CXCR}^{+}, \mathrm{PDI}^{+} \mathrm{T}$ cells as follicular T cells (Tfh) , $\mathrm{CD} 4^{+}$, $\mathrm{CCR}^{+}, \mathrm{CD}^{+}, \mathrm{IL} 17 \mathrm{~A}^{+} \mathrm{T}$ cells as Th17 cells, $\mathrm{CD} 4^{+}, \mathrm{CD} 25^{+}$, foxp $3^{+} \mathrm{T}$ cells as regulatory $\mathrm{T}$ cells (Treg), $\mathrm{CD}^{+}, \mathrm{CXCR}^{+}$, $\mathrm{CD} 4^{+}, \mathrm{IFN}-\gamma^{+} \mathrm{T}$ cells as Thl cells, and $\mathrm{CD} 4^{+}, \mathrm{IL}-4^{+} \mathrm{T}$ cells were evaluated as Th2 cells. The ESR was studied with an
iSED (Alcor Scientific, Smithfield, RI) device. CRP analyzes were carried out using a spectrophotometric method with an Abbott C 16000 (Abbott Park, IL) brand device.

\section{Statistical analysis}

Statistical analysis was performed using SPSS version 21.0 (IBM Co., Armonk, NY). Numerical data were indicated with mean, standard deviation, median, minimum and maximum values. Categorical data were shown with numbers and percentages. The Wilcoxon test was used to investigate the relationships between dependent measures, and the Mann-Whitney $U$-test was used to investigate the relationships between independent measures. The relationship between two numerical variables was analyzed using the Spearman correlation coefficient (r). Statistical significance was accepted for a value of $P<0.05$.

\section{RESULTS}

Forty-eight patients who were diagnosed with PHN and started treatment were included in the study. However, eight patients were excluded from the study because they did not meet the appropriate criteria (Fig. 1). Of the 40 patients, 21 were women (52.5\%), 19 (47.5\%) were men. The mean age was $60.2 \pm 11.8$, and the median age was 61 (22-76). While $35 \%$ of patients had diabetes mellitus (DM); all patients with DM also had diabetic neuropathy. The diabetic neuropathy diagnosis was based on clinical symptoms or signs and expert panels at the International Symposium on Diabetic Neuropathy in Toronto, 2009 [32]. Information on the presence of comorbidities in patients is given in Table 1.

When immunological marker and inflammation pa-

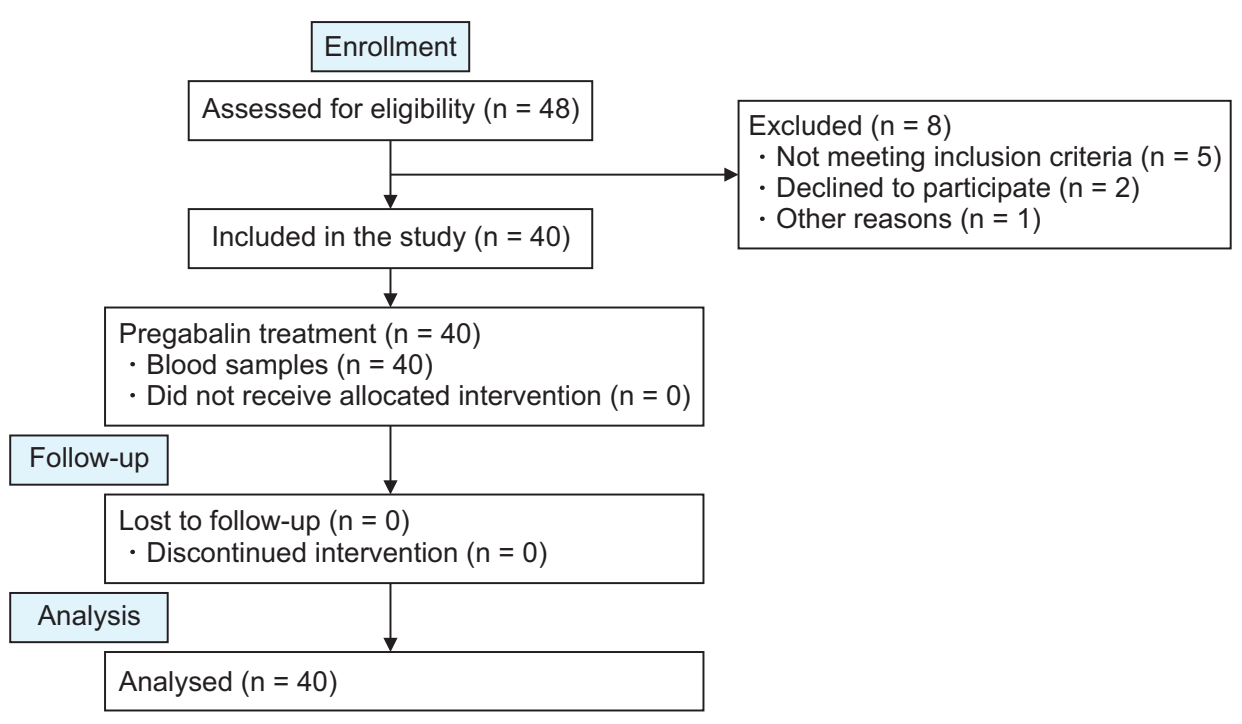

Fig. 1. Flowchart of our study. 
rameter levels were compared before and after treatment, the helper $\mathrm{T}$ cell ratio $\left(\mathrm{CD}^{+}, \mathrm{CD}^{+}\right)$was $30.28 \pm 12.27 \%$ before treatment. It was $34.93 \pm 11.70 \%$ after treatment, and there was a statistically significant increase $(P=0.028)$. Th17 was $4.75 \pm 5.02 \%$ before treatment and $5.80 \pm 3.13 \%$ after treatment, and there was a statistically significant increase $(P=0.036)$. While the CRP value was $8.44 \pm 9.32 \mathrm{mg} /$ $\mathrm{L}$ before treatment, it was $3.00 \pm 3.61 \mathrm{mg} / \mathrm{L}$ after treatment, and there was a statistically significant decrease $(P=0.001)$. While the ESR value was $19.54 \pm 11.57 \mathrm{~mm} / \mathrm{hr}$ before treatment, it was $9.83 \pm 7.77 \mathrm{~mm} / \mathrm{hr}$ after treatment. There was a statistically significant decrease $(P=0.001)$. The pretreatment NRS score of 40 patients included in the study was 8 . While it was $8.00 \pm 0.88$, this value was $3.00 \pm 0.84$ after the treatment, and a statistically significant $(P=0.001)$ decrease was detected (Table 2).

The immunological marker and inflammation parameter levels of DM patients were coimpared before and after treatment. There was not a significant relationship in immunological marker levels. There was no significant relationship between pre-treatment and post-treatment immunological marker levels in $\mathrm{DM}+$ patients. However,

Table 1. Comorbidity of the patients

\begin{tabular}{cr}
\hline Comorbidity & Value \\
\hline Diabetes mellitus & \\
No & $26(65.0)$ \\
Yes & $14(35.0)$ \\
At least one comorbidity & \\
No & $6(15.0)$ \\
Yes & $34(85.0)$ \\
\hline
\end{tabular}

Values are presented as number (\%). there was a significant decrease in CRP, ESR, and NRS values after treatment in patients with DM. When the immunological marker and inflammation parameter levels of non-DM patients were compared before and after treatment, the helper $\mathrm{T}$ cell ratio $\left(\mathrm{CD}^{+}, \mathrm{CD}^{+}\right)$was 27.41 $\pm 10.78 \%$ before treatment $35.43 \pm 8.93 \%$ after treatment, and there was a significant increase $(P=0.002)$. In patients without DM, the Th17 (CD4 ${ }^{+}, \mathrm{IL}-17 \mathrm{~A}^{+} \mathrm{T}$ cells) ratio was 4.25 $\pm 4.01 \%$ before treatment and $5.67 \pm 2.34 \%$ after treatment, and there was a significant increase after treatment $(P=$ 0.037). There was a significant decrease in CRP, ESR, and NRS values after treatment in patients without DM (Table 3). The change in Th17 cell ratios before and during the treatment period in DM and non-DM patients is also included in Fig. 2.

\section{DISCUSSION}

Despite extensive research, the pathophysiological mechanisms which generate neuropathic pain have not been clearly revealed yet. Recent publications and increasing evidence indicate that the immune system plays an essential role in developing neuropathic pain [13]. In this study, Th1, Th2, Th17, and Treg (CD4, CXCR5, CCR6, FOXP3, CD25, IFN- $\gamma$, IL-17 ve IL-4) cell levels before and after treatment were examined to evaluate the role of immune mechanisms in the development and chronicity of neuropathic pain in patients with PHN and the effectiveness of pregabalin treatment on these mechanisms. According to the present study's results, while $\mathrm{CD}^{+} \mathrm{T}$ cell and Th17 cell levels increased with pregabalin treatment, Treg cell levels remained unchanged, and $\mathrm{T}$ cell shift improved. Accord-

Table 2. Comparison of immunological marker and inflammation parameter levels and NRS scores of patients before and after treatment

\begin{tabular}{|c|c|c|c|}
\hline $\begin{array}{l}\text { Immunological markers and inflammation } \\
\text { parameter levels }\end{array}$ & Before treatment $(n=40)$ & After treatment $(n=40)$ & $P$ value \\
\hline $\mathrm{CD}^{+}, \mathrm{CD}^{+} \mathrm{T}$ cells $\%$ & $30.28 \pm 12.27$ & $34.93 \pm 11.70$ & $0.028 *$ \\
\hline $\mathrm{CD}^{+}, \mathrm{PD}^{+}, \mathrm{CXCR}^{+}{ }^{\mathrm{T}}$ cells$\%$ (Tfh) & $2.61 \pm 0.96$ & $2.59 \pm 2.25$ & 0.208 \\
\hline $\mathrm{CD}^{+}, \mathrm{CXCR}^{+}{ }^{\mathrm{T}}$ cells$\%(\mathrm{Th} 1)$ & $28.32 \pm 11.29$ & $25.20 \pm 11.92$ & 0.091 \\
\hline $\mathrm{CD}^{+}, \mathrm{CCR}^{+}{ }^{\top}$ cells$\%$ (Th17) & $9.41 \pm 5.44$ & $10.24 \pm 6.14$ & 0.834 \\
\hline $\mathrm{CD}^{+}, \mathrm{FOXP3}^{+} \mathrm{T}$ cells$\%$ (Treg) & $5.59 \pm 2.56$ & $5.56 \pm 1.98$ & 0.957 \\
\hline $\mathrm{CD}^{+}, \mathrm{CD} 25^{+} \mathrm{T}$ cells$\%$ (Treg) & $6.02 \pm 2.77$ & $5.63 \pm 2.04$ & 0.476 \\
\hline $\mathrm{CD}^{+}, \mathrm{IFN}-\gamma^{+} \mathrm{T}$ cells$\%$ (Th1) & $23.05 \pm 18.80$ & $20.09 \pm 15.05$ & 0.426 \\
\hline $\mathrm{CD}^{+}, \mathrm{IL}^{-17 \mathrm{~A}^{+}} \mathrm{T}$ cells$\%$ (Th17) & $4.75 \pm 5.02$ & $5.80 \pm 3.13$ & $0.036 *$ \\
\hline $\mathrm{CD}^{+}, \mathrm{IL}-4^{+} \mathrm{T}$ cells$\%$ (Th2) & $4.33 \pm 3.64$ & $3.44 \pm 2.73$ & 0.261 \\
\hline $\mathrm{ESR}(\mathrm{mm} / \mathrm{hr})$ & $19.54 \pm 11.57$ & $9.83 \pm 7.77$ & $0.001 *$ \\
\hline $\mathrm{CRP}(\mathrm{mg} / \mathrm{L})$ & $8.44 \pm 9.32$ & $3.00 \pm 3.61$ & $0.001 *$ \\
\hline NRS & $8.00 \pm 0.88$ & $3.00 \pm 0.84$ & $0.001 *$ \\
\hline
\end{tabular}

Values are presented as mean \pm standard deviation.

Tfh: T follicular helper cells, ESR: erythrocyte sedimentation rate, CRP: C-reactive protein, NRS: numeric rating scale.

$* P<0.05$, significant. 
Table 3. Comparison of immunological marker and inflammation parameter levels before and after treatment in DM patients and comparison of the immunological marker and inflammation parameter levels before and after treatment in patients without DM

\begin{tabular}{|c|c|c|c|c|c|c|}
\hline \multirow{2}{*}{$\begin{array}{l}\text { Immunological markers and } \\
\text { inflammation parameter levels }\end{array}$} & \multicolumn{3}{|c|}{$\mathrm{DM}+$} & \multicolumn{3}{|c|}{ DM- } \\
\hline & Before treatment & After treatment & $P$ value & Before treatment & After treatment & $P$ value \\
\hline $\mathrm{CD}^{+}, \mathrm{CD}^{+} \mathrm{T}$ cells $\%$ & $35.59 \pm 13.46$ & $33.99 \pm 15.98$ & 0.638 & $27.41 \pm 10.78$ & $35.43 \pm 8.93$ & 0.002 \\
\hline $\mathrm{CD}^{+}, \mathrm{PD}^{+}, \mathrm{CXCR}^{+}{ }^{\mathrm{T}}$ cells$\%$ (Tfh) & $2.81 \pm 0.91$ & $2.47 \pm 1.20$ & 0.245 & $2.50 \pm 0.98$ & $2.65 \pm 2.66$ & 0.453 \\
\hline $\mathrm{CD}^{+}, \mathrm{CXCR}^{+} \mathrm{T}$ cells$\%$ (Th1) & $28.20 \pm 14.92$ & $26.07 \pm 13.05$ & 0.701 & $28.38 \pm 9.10$ & $24.73 \pm 11.49$ & 0.110 \\
\hline $\mathrm{CD}^{+}, \mathrm{CCR}^{+}{ }^{\mathrm{T}}$ cells$\%$ (Th17) & $10.46 \pm 7.63$ & $12.50 \pm 8.20$ & 0.778 & $8.83 \pm 3.85$ & $9.02 \pm 4.39$ & 0.872 \\
\hline $\mathrm{CD}^{+}, \mathrm{FOXP3}^{+} \mathrm{T}$ cells$\%$ (Treg) & $4.92 \pm 2.02$ & $5.36 \pm 2.33$ & 0.530 & $5.95 \pm 2.77$ & $5.66 \pm 1.80$ & 0.576 \\
\hline $\mathrm{CD}^{+}, \mathrm{CD}^{2} 5^{+} \mathrm{T}$ cells\% (Treg) & $5.67 \pm 2.38$ & $5.79 \pm 2.18$ & 0.925 & $6.21 \pm 2.99$ & $5.54 \pm 2.00$ & 0.354 \\
\hline $\mathrm{CD}^{+}, \mathrm{IFN}-\gamma^{+} \mathrm{T}$ cells\% (Th1) & $20.33 \pm 19.33$ & $20.94 \pm 17.50$ & 0.807 & $24.40 \pm 18.76$ & $19.63 \pm 13.90$ & 0.258 \\
\hline $\mathrm{CD}^{+}, \mathrm{IL}-17 \mathrm{~A}^{+} \mathrm{T}$ cells$\%$ (Th17) & $5.67 \pm 6.58$ & $6.02 \pm 4.32$ & 0.510 & $4.25 \pm 4.01$ & $5.67 \pm 2.34$ & 0.037 \\
\hline $\mathrm{CD}^{+}, \mathrm{IL}-4^{+} \mathrm{T}$ cells$\%$ (Th2) & $3.15 \pm 2.03$ & $3.75 \pm 3.11$ & 0.754 & $4.97 \pm 4.16$ & $3.26 \pm 2.55$ & 0.148 \\
\hline $\mathrm{ESR}(\mathrm{mm} / \mathrm{hr})$ & $20.31 \pm 10.16$ & $9.50 \pm 6.50$ & 0.002 & $19.11 \pm 12.43$ & $10.00 \pm 8.48$ & $<0.001$ \\
\hline CRP (mg/L) & $11.20 \pm 8.55$ & $4.13 \pm 4.44$ & 0.001 & $6.95 \pm 9.52$ & $2.39 \pm 2.98$ & $<0.001$ \\
\hline NRS & $8.84 \pm 0.86$ & $3.28 \pm 0.72$ & 0.001 & $8.11 \pm 0.90$ & $3.50 \pm 0.90$ & $<0.001$ \\
\hline
\end{tabular}

Values are presented as mean \pm standard deviation.

DM: diabetes mellitus, Tfh: T follicular helper cells, ESR: erythrocyte sedimentation rate, CRP: C-reactive protein, NRS: numeric rating scale.

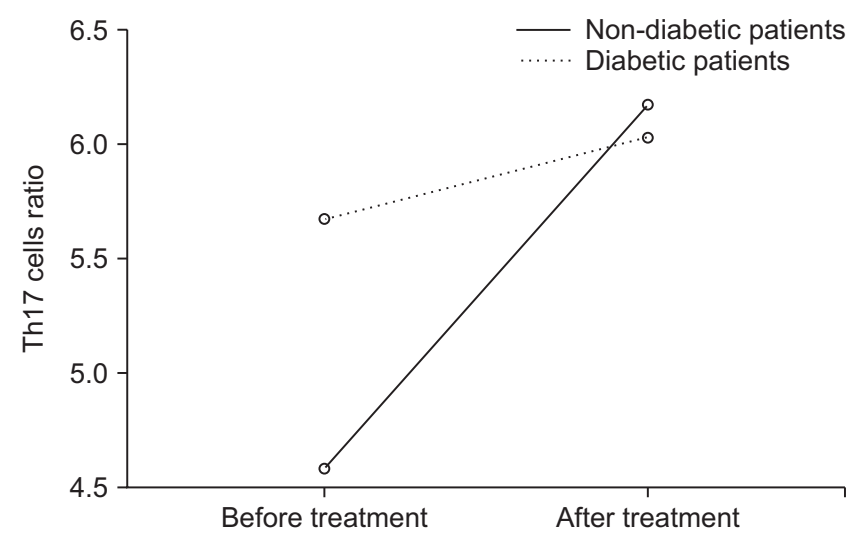

Fig. 2. Change of $\mathrm{CD} 4^{+}$, IL-17A ${ }^{+} \mathrm{T}$ cells $\%$ (Th17) cell ratios with treatment in $\mathrm{DM}^{+}$and $\mathrm{DM}$ patients. DM: diabetes mellitus.

ing to this study, CRP and ESR values were significantly lower $(P<0.001)$ after three months of treatment compared to before treatment. It has been proven in previous studies that the acute inflammation period of neuropathic pain is associated with high CRP [20]. A significant decrease in ESR and CRP values after treatment, known as positive acute phase reactants, suggests that the inflammatory process that plays a role in neuropathic pain's pathogenesis decreases after pregabalin treatment. However, decreases in CRP and ESR might result from the natural course of the PHN. Evaluation using randomized controlled clinical studies conducted with large patient groups is needed.

Previous studies have shown that the most critical risk factor in transforming acute herpes zoster to PHN is age. Kanazi et al. [33] found that $50 \%$ of the patients with PHN were over the age of 60 , and the rate of PHN was $75 \%$, especially over the age of 70 . The average age of the study group was $60.2 \pm 11.8$. Although it has been determined that PHN is seen more in women, there has been no difference between genders in recent studies [34]. In this study, 21 of the patients were women (52.5\%), and 19 (47.5\%) were men, and there was no significant difference found in terms of gender.

Patients with a deficiency in $\mathrm{CD} 4^{+}$and $\mathrm{CD} 8^{+} \mathrm{T}$ cells are at risk for VZV infection and the subsequent development of PHN [35]. Asanuma et al. [36] attributed the increase in PHN development to the decrease in $\mathrm{CD} 4^{+} \mathrm{T}$ cell ratio in the elderly. However, another study conducted in 2009 found no difference in $\mathrm{CD}^{+}$and $\mathrm{CD}^{+} \mathrm{T}$ cell levels in patients with and without PHN [14]. A significant increase was found in the present study in $\mathrm{CD} 4^{+} \mathrm{T}$ cell levels with pregabalin treatment (Table 2). Therefore, it was concluded that a low $\mathrm{CD} 4^{+} \mathrm{T}$ cell value is a risk factor for developing neuropathic pain and PHN. The increase in $\mathrm{CD}^{+}$ $\mathrm{T}$ cells after pregabalin treatment significantly reduces NRS scores and decreases neuropathic pain symptoms. However, it is not certain whether the increase in $\mathrm{CD} 4^{+} \mathrm{T}$ cells results from pregabalin treatment or is a natural consequence of disease recovery. This may be the subject of future studies.

For years, neuropathic pain has been thought to be associated with proinflammatory cytokines, and anti-inflammatory treatments targeting cytokines have been evaluated in various animal studies [37]. In a study conducted on rats, it was found that after peripheral nerve damage, treatment with CD28 super antagonist (CD28SupA) increased Treg cell population, and this increase decreased mechanical pain hypersensitivity. On the contrary, depletion of Treg cells has moderately increased mechanical pain hypersensitivity after peripheral nerve damage in 
rats. Recent studies on this subject have shown that AntiCD25 treatment partially eliminates Treg cells or temporarily deactivates them by reducing CD25 [38]. Tests on Treg cell expansion in humans have been stopped due to life-threatening side effects [39]. The present study found that pregabalin treatment did not change Treg cell levels (Table 2).

Th17 cells secreting IL-17 have been shown to play a definite role in the etiology of Type-1 DM and play an essential role in inflammation, insulin resistance, and Type-2 DM [40]. Thirty-five percent of the patients in this study had DM. All patients with DM also had diabetic neuropathy. When the graph of the change in IL-17 levels from pre-treatment to post-treatment in patients with and without DM is examined, the high level of IL-17 at the time of initial diagnosis in patients with DM suggests that there may be a relationship between existing chronic diabetic neuropathy and IL-17 (Fig. 2). In neuropathic pain models, the effect of the increase in IL-17 level on allodynia formation and thermal hyperalgesia formation has been demonstrated [41]. It is also found that the increase in IL-17 levels increased with time [42]. In this study, no significantly higher levels of IL-17 at the end of 3 months are supported by the literature. This suggests that IL-17 may have an effect on chronic pain rather than acute pain. IL-17 inhibiting monoclonal antibodies are being studied as a treatment modality [30]. In the future, the anti-inflammatory cytokine-targeted therapy approach will be the cornerstone of neuropathic pain treatment. Current scientific evidence; Although limited to in vitro experiments and animal studies, the authors think that studies on neuropathic pain treatment will focus on IL-17 and anti-inflammatory cytokine-targeted therapy in the coming years.

A study investigating neuropathic pain mechanisms found that proinflammatory Thl7 significantly decreased and anti-inflammatory Treg cells increased in patients with neuropathic pain. This condition has been named the "T cell shuffle" and has been accepted as a finding in favor of chronic neuropathic pain. In the same study, no significant difference was found in IFN- $\gamma$ levels [12]. In this study, IL-17s released from Th17 cells were compared before and after treatment with Treg cells. While the pretreatment IL-17/Treg ratio decreased in favor of Treg cells, after treatment, this ratio increased in favor of IL-17. Therefore, following the literature, it was found that patients who developed PHN had T cell shifts. T cell recovery improved after pregabalin treatment. Similar to the other studies, no difference was found in IFN- $\gamma$ levels.

This study had some limitations. First of all, markers such as Th17 (IL-17), Treg cells, and IFN- $\gamma$ were studied instead of the immunological markers studied extensively in previous studies. More meaningful results could be obtained with a broader range of immunological markers to be reviewed. Of the 40 patients included in the study, 14 also had diabetic neuropathy. Therefore, it is not clear whether diabetic neuropathy affects the results of these patients. Also, 34 patients had at least one comorbidity, such as asthma, hypertension, and DM. When subgroup analysis was performed due to at least one comorbidity, no difference was found in immunological marker and inflammation parameter levels before and after treatment. This result was attributed to the different comorbidities and non-homogenized patient groups. Besides, there were only six patients without any other disease among the patients included in the study. The lack of a significant difference may be the group's insufficient number of subjects without comorbidities. The effect of different comorbidities on immunological markers may be the subject of future randomized controlled studies. The patients were receiving only pregabalin treatment for neuropathic pain. However, patients with comorbidities had additional therapies for these diseases.

In conclusion, in this study the effect of treatment with pregabalin on immunological markers was examined, which is recommended as a first-line pharmacological agent in neuropathic pain treatment. Significant differences were detected after the therapy in the immunological markers, especially $\mathrm{CD} 4^{+} \mathrm{T}$ cell, Th17 cell levels, and T cell shift. These differences in the immunological markers reveal that the immune system's role in the pathogenesis of neuropathic pain is much more vital than previously thought. However, randomized controlled studies in different and larger patient populations are needed to clearly prove pregabalin's effect on these mechanisms. The authors believe that an immunologically based treatment approach will be the critical element of future treatment, especially in treating neuropathic pain.

\section{ACKNOWLEDGMENTS}

We want to thank Professor Doctor Ismail Reisli and Seyma Celikbilek Celik for their support during our studies in the immunology laboratory.

\section{CONFLICT OF INTEREST}

No potential conflict of interest relevant to this article was reported. 


\section{FUNDING}

The study was financed by the Scientific Research Projects Coordinator of Necmettin Erbakan University (project number: 181518025).

\section{ORCID}

Aysel Mercan, https://orcid.org/0000-0002-6876-1573

Sema Tuncer Uzun, https://orcid.org/0000-0002-6205-1706

Sevgi Keles, https://orcid.org/0000-0001-7344-8947

Gulcin Hacibeyoglu, https://orcid.org/0000-0002-9438-3414

Resul Yilmaz, https://orcid.org/0000-0002-5527-2893

Ruhiye Reisli, https://orcid.org/0000-0002-1616-5497

\section{REFERENCES}

1. Toth C, Lander J, Wiebe S. The prevalence and impact of chronic pain with neuropathic pain symptoms in the general population. Pain Med 2009; 10: 918-29.

2. Tian L, Ma L, Kaarela T, Li Z. Neuroimmune crosstalk in the central nervous system and its significance for neurological diseases. J Neuroinflammation 2012; 9: 155.

3. Calvo M, Dawes JM, Bennett DL. The role of the immune system in the generation of neuropathic pain. Lancet Neurol 2012; 11: 629-42.

4. Campbell JN, Meyer RA. Mechanisms of neuropathic pain. Neuron 2006; 52: 77-92.

5. Feldman EL, Callaghan BC, Pop-Busui R, Zochodne DW, Wright DE, Bennett DL, et al. Diabetic neuropathy. Nat Rev Dis Primers 2019; 5: 41.

6. Johnson RW, Rice AS. Clinical practice. Postherpetic neuralgia. N Engl J Med 2014; 371: 1526-33.

7. Opstelten W, McElhaney J, Weinberger B, Oaklander AL, Johnson RW. The impact of varicella zoster virus: chronic pain. J Clin Virol 2010; 48 Suppl 1: S8-13.

8. Hadley GR, Gayle JA, Ripoll J, Jones MR, Argoff CE, Kaye RJ, et al. Post-herpetic neuralgia: a review. Curr Pain Headache Rep 2016; 20: 17.

9. Yawn BP, Saddier P, Wollan PC, St Sauver JL, Kurland MJ, Sy LS. A population-based study of the incidence and complication rates of herpes zoster before zoster vaccine introduction. Mayo Clin Proc 2007; 82: 1341-9.

10. Drolet M, Brisson M, Schmader K, Levin M, Johnson R, Oxman $\mathrm{M}$, et al. Predictors of postherpetic neuralgia among patients with herpes zoster: a prospective study. J Pain 2010; 11: 1211-21.

11. Bayat A, Burbelo PD, Browne SK, Quinlivan M, Martinez B, Holland SM, et al. Anti-cytokine autoantibodies in postherpetic neuralgia. J Transl Med 2015; 13: 333.
12. Luchting B, Rachinger-Adam B, Heyn J, Hinske LC, Kreth S, Azad SC. Anti-inflammatory T-cell shift in neuropathic pain. J Neuroinflammation 2015; 12: 12.

13. Kiguchi N, Kobayashi D, Saika F, Matsuzaki S, Kishioka S. Pharmacological regulation of neuropathic pain driven by inflammatory macrophages. Int J Mol Sci 2017; 18: 2296.

14. Zhu SM, Liu YM, An ED, Chen QL. Influence of systemic immune and cytokine responses during the acute phase of zoster on the development of postherpetic neuralgia. J Zhejiang Univ Sci B 2009; 10: 625-30.

15. Kim CF, Moalem-Taylor G. Interleukin-17 contributes to neuroinflammation and neuropathic pain following peripheral nerve injury in mice. J Pain 2011; 12: 370-83.

16. Hung AL, Lim M, Doshi TL. Targeting cytokines for treatment of neuropathic pain. Scand J Pain 2017; 17: 287-93.

17. Lees JG, Duffy SS, Perera CJ, Moalem-Taylor G. Depletion of Foxp3+ regulatory $\mathrm{T}$ cells increases severity of mechanical allodynia and significantly alters systemic cytokine levels following peripheral nerve injury. Cytokine 2015; 71: 207-14.

18. Xing Q, Hu D, Shi F, Chen F. Role of regulatory T cells in patients with acute herpes zoster and relationship to postherpetic neuralgia. Arch Dermatol Res 2013; 305: 715-22.

19. Ji RR, Chamessian A, Zhang YQ. Pain regulation by nonneuronal cells and inflammation. Science 2016; 354: 572-7.

20. Ren K, Dubner R. Interactions between the immune and nervous systems in pain. Nat Med 2010; 16: 1267-76.

21. Davoli-Ferreira M, de Lima KA, Fonseca MM, Guimarães RM, Gomes FI, Cavallini MC, et al. Regulatory T cells counteract neuropathic pain through inhibition of the Th1 response at the site of peripheral nerve injury. Pain 2020; 161: 1730-43.

22. Moalem G, Xu K, Yu L. T lymphocytes play a role in neuropathic pain following peripheral nerve injury in rats. Neuroscience 2004; 129: 767-77.

23. Draleau K, Maddula S, Slaiby A, Nutile-McMenemy N, De Leo J, Cao L. Phenotypic identification of spinal cord-infiltrating CD4+ T lymphocytes in a murine model of neuropathic pain. J Pain Relief 2014; Suppl 3: 003.

24. Sah DW, Ossipo MH, Porreca F. Neurotrophic factors as novel therapeutics for neuropathic pain. Nat Rev Drug Discov 2003; 2: 460-72.

25. Kobayashi Y, Kiguchi N, Fukazawa Y, Saika F, Maeda T, Kishioka S. Macrophage-T cell interactions mediate neuropathic pain through the glucocorticoid-induced tumor necrosis factor ligand system. J Biol Chem 2015; 290: 12603-13.

26. Kiguchi N, Kobayashi Y, Saika F, Sakaguchi H, Maeda T, Kishioka S. Peripheral interleukin-4 ameliorates inflammatory macrophage-dependent neuropathic pain. Pain 2015; 156: 684-93.

27. Hao S, Mata M, Glorioso JC, Fink DJ. HSV-mediated expression of interleukin-4 in dorsal root ganglion neurons reduces neuropathic pain. Mol Pain 2006; 2: 6. 
28. Sorge RE, Mapplebeck JC, Rosen S, Beggs S, Taves S, Alexander JK, et al. Different immune cells mediate mechanical pain hypersensitivity in male and female mice. Nat Neurosci 2015; 18: 1081-3.

29. Austin PJ, Kim CF, Perera CJ, Moalem-Taylor G. Regulatory T cells attenuate neuropathic pain following peripheral nerve injury and experimental autoimmune neuritis. Pain 2012; 153: 1916-31.

30. Langley RG, Elewski BE, Lebwohl M, Reich K, Griffiths CE, Papp K, et al. Secukinumab in plaque psoriasis--results of two phase 3 trials. N Engl J Med 2014; 371: 326-38.

31. Attal N, Cruccu G, Baron R, Haanpää M, Hansson P, Jensen TS, et al. EFNS guidelines on the pharmacological treatment of neuropathic pain: 2010 revision. Eur J Neurol 2010; 17: 1113-e88.

32. Tesfaye S, Boulton AJ, Dyck PJ, Freeman R, Horowitz M, Kempler P, et al. Diabetic neuropathies: update on definitions, diagnostic criteria, estimation of severity, and treatments. Diabetes Care 2010; 33: 2285-93.

33. Kanazi G, Johnson R, Dworkin R. Treatment of postherpetic neuralgia-an update. J Peripher Nerv Syst 2000; 5: 250.

34. Güleç H, Babayiğit M, Kütük S, Şahap M, Tutal Z, Kurtay A, et al. Combination treatment of post-herpetic neuralgia. J Contemp Med 2014; 4(2 EK): 100-37.

35. Higa K, Noda B, Manabe H, Sato S, Dan K. T-lymphocyte subsets in otherwise healthy patients with herpes zoster and relationships to the duration of acute herpetic pain. Pain 1992; 51: 111-8.
36. Asanuma H, Sharp M, Maecker HT, Maino VC, Arvin AM. Frequencies of memory $\mathrm{T}$ cells specific for varicella-zoster virus, herpes simplex virus, and cytomegalovirus by intracellular detection of cytokine expression. J Infect Dis 2000; 181: 859-66.

37. Austin PJ, Moalem-Taylor G. The neuro-immune balance in neuropathic pain: involvement of inflammatory immune cells, immune-like glial cells and cytokines. J Neuroimmunol 2010; 229: 26-50.

38. Kohm AP, McMahon JS, Podojil JR, Begolka WS, DeGutes M, Kasprowicz DJ, et al. Cutting Edge: anti-CD25 monoclonal antibody injection results in the functional inactivation, not depletion, of CD4+CD25+ T regulatory cells. J Immunol 2006; 176: 3301-5.

39. Suntharalingam G, Perry MR, Ward S, Brett SJ, Castello-Cortes A, Brunner MD, et al. Cytokine storm in a phase 1 trial of the anti-CD28 monoclonal antibody TGN1412. N Engl J Med 2006; 355: 1018-28.

40. Abdel-Moneim A, Bakery HH, Allam G. The potential pathogenic role of IL-17/Th17 cells in both type 1 and type 2 diabetes mellitus. Biomed Pharmacother 2018; 101: 287-92.

41. Noma N, Khan J, Chen IF, Markman S, Benoliel R, Hadlaq E, et al. Interleukin-17 levels in rat models of nerve damage and neuropathic pain. Neurosci Lett 2011; 493: 86-91.

42. Kleinschnitz C, Hofstetter HH, Meuth SG, Braeuninger S, Sommer C, Stoll G. T cell infiltration after chronic constriction injury of mouse sciatic nerve is associated with interleukin-17 expression. Exp Neurol 2006; 200: 480-5. 